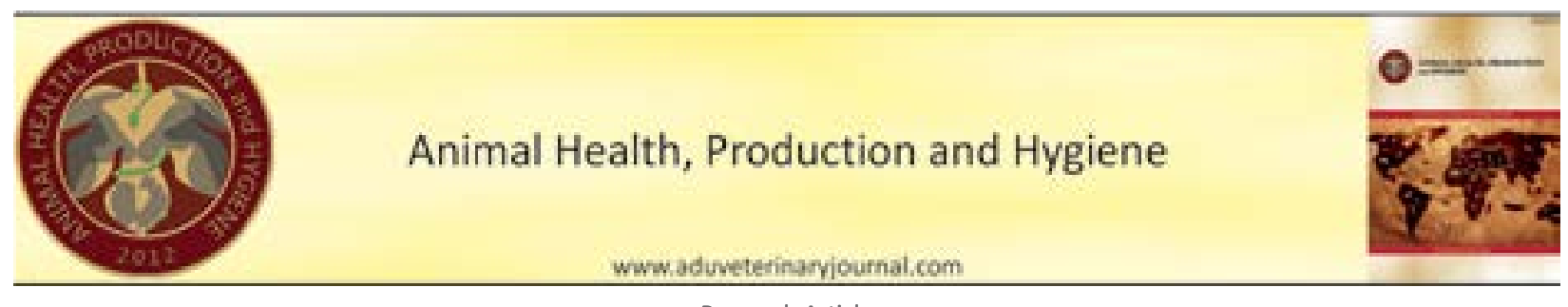

Research Article

\title{
The Effects of Footbath Management on Digital Dermatitis Distribution
}

\author{
Oğuzhan KALYONCU ${ }^{1 *}{ }^{\circledR}$, Emre GÜRDAL $^{2}{ }^{\circledR}$, Yalçın Alper ÖZTURAN ${ }^{3}$, ibrahim AKIN ${ }^{3}$ \\ ${ }^{1}$ Clinic for Cattle, University of Veterinary Medicine Hannover, Foundation, Hannover, Germany, ${ }^{3}$ Department of Veterinary Surgery, Faculty of \\ Veterinary Medicine, Adnan Menderes University, Aydin, Turkey, ${ }^{2}$ Department of Food Hygiene and Technology, Faculty of Veterinary Medicine, \\ Adnan Menderes University, Aydin, Turkey
}

\begin{abstract}
A B S T R A C T
Digital dermatitis (DD) is a common infectious disease that causes economic losses and lameness. In order to keep DD under control, the usage of footbath is very important in intensive dairy farms. It was aimed to determine the relationship between footbath use and the number of active lesions related to DD. In total of 1527 cattle from 6 dairy farms were included in the study to assess and correlate the prevalence of DD and footbath practices. Information about the farm structure and management practice of footbaths was obtained through a questionnaire. It was inspected all feet of cattle with DD lesions during the milking time and scored the lesions using six M-stages. Thereafter, the chi square test was performed to investigate the relation between digital dermatitis prevalence and footbath applications. DD lesions in 500 feet (8.2\%) of 338 (22.1\%) was observed in dairy cows. Farms using dry manure as a bedding material showed a higher DD prevalence $(p<0.001)$. Farms using formalin footbath had the lowest DD lesions, whereas copper sulfate $\left(\mathrm{CuSO}_{4}\right)$ practice had the highest prevalence $(p<0.001)$. Periodically renewed footbaths showed a statistically lower DD prevalence in farms $(p<0.001)$. We concluded that the convenient design and management of footbath might help to reduce the prevalence of digital dermatitis in dairy farms.
\end{abstract}

Keywords: Cattle, copper sulfate, digital dermatitis, footbath, formalin

\section{Ayak Banyosu Kullanımının Digital Dermatitis Dağılımına Etkileri}

\section{ÖZET}

Digital dermatitis (DD); ekonomik kayıplara ve topallığa neden olan yaygın bir enfeksiyöz hastalıktır. Digital dermatitis'। lea ya altında tutmak için, entansif süt çiftliklerinde, ayak banyolarının kullanımı çok önemlidir. Bu çalışmanın amacı; ayak banyosu kullanımı ile DD’ye bağlı aktif lezyon sayısı arasındaki ilişkiyi araştırmaktı. DD lea yak banyosu uygulamalarının yaygınlığını değerlendirmek ve ilişkilendirmek için, 6 süt çiftliğinden toplam 1527 sığır çalışmaya dahil edildi. Çiftlik yapısı ve ayak banyolarının yönetim pratiği hakkındaki bilgiler, anket yoluyla elde edildi. İneklerin ayaklarındaki DD lezyonları, sağım periyodu sırasında altı M-aşaması kullanılarak skorlandı. Daha sonra DD prevalansı lea yak banyosu uygulamaları arasındaki ilişkiyi araştırmak için ki kare testi yapıldı. Çiftliklerdeki 338 (\%22.1) süt ineğinin 500 adet ayağında $(\% 8,2)$ DD lezyonları gözlemlendi. Altlık olarak kuru gübre kullanan çiftlikler, daha yüksek bir DD prevalansı gösterdi $(p<0,001)$. Ayak banyosunda formalin kullanan çiftlikler en düşük DD lezyonlarına sahipken, bakır sülfat $\left(\mathrm{CuSO}_{4}\right)$ kullanan çiftlikler en yüksek prevalansa sahipti $(p<0,001)$. Ayak banyolarını periyodik olarak yenileyen çiftlikler, istatistiksel olarak daha düşük bir DD prevalansı gösterdi $(p<0,001)$. Yapılan çalışmalar ve elde edilen sonuçlar doğrultusunda, uygun ayak banyosu tasarımı ve yönetiminin süt çiftliklerinde DD prevalansının azaltılmasına yardımcı olabileceği sonucuna varıldı.

Anahtar Kelimeler: Ayak banyosu, bakır sülfat, digital dermatitis, formalin, sığır

*Corresponding Author: Oğuzhan KALYONCU: Clinic for Cattle, University of Veterinary Medicine Hannover, Foundation, Hannover, Germany, e-mail: Oguzhan.Kalyoncu@tiho-hannover.de

Received Date: 13.09.2021 - Accepted Date: 15.12.2021

DOI: 10.53913 /aduveterinary.993485 


\section{Introduction}

Digital dermatitis (DD) is a common infectious foot lesion in livestock animals typically in intensively managed dairy farming systems (Blowey, 2005; Cheli \& Mortellaro, 1974; Cramer et al., 2008; Holzhauer et al., 2006; Read \& Walker, 1998; Solano et al., 2016). DD is one of the most common causes of cattle lameness, which effects animal welfare and results with economic losses (Apley, 2015; Blowey \& Sharp, 1988; Gomez et al., 2015). DD lesions can be painful and last for long terms (Bruijnis et al., 2012; Dopfer et al., 2012). Moreover, it can trigger disruptions in foot conformation that promote other infectious foot lesions (Gomez et al., 2015). In addition, DD has significant negative financial consequences associated with reduced milk production, reduced fertility rate, increased risk of culling, and increased cost of care (Akin \& Akin, 2018; Bruijnis et al., 2010; Cha et al., 2010; Ettema et al., 2010; Holzhauer et al., 2008) due to its high incidence. Digital dermatitis is a multifactorial and a multi bacterial disease. Treponema spp. is frequently isolated from DD lesions (Döpfer et al., 2012; Gomez et al., 2015; Krull et al., 2016). This anaerobic spirochete bacteria can be identified in lesions (Blowey et al., 1994), indicating that they are invasive. Infected hoof trimming equipment and contact with manure are potential routes of transmission (Evans et al., 2012; Gillespie et al., 2020). Therefore, DD prevention techniques primarily involve the good hygiene practices and dry environment. To prevent the spreading of DD, host susceptibility (Scholey et al., 2010), inadequate hygiene and wet environments (Rodríguez-Lainz et al., 1996) should be eliminated and optimized.

Several control strategies have been recommended, including maintaining a clean, dry environment, individual topical treatment of affected cows, and herd-level strategies, including footbath usage (Dopfer et al., 2012; Laven \& Logue, 2006; Nuss, 2006). Early intervention and effective topical treatments of active DD lesions increase cure rates and minimize spreading of the infection. In addition, an efficient footbath program can prevent active lesions from emerging (Dopfer et al., 2012). Footbaths are a common preventive method due to labor force needed to manage large numbers of sick cows, with strong evidence from intervention trials supporting the effectiveness of footbathing in reducing the incidence of DD (Fjeldaas et al., 2014; Laven \& Logue, 2006; Relun et al., 2012; Speijers et al., 2010). The most common substances in footbath practice are $\mathrm{CuSO}_{4}$ and formalin. Unfortunately, $\mathrm{CuSO}_{4}$ has adverse environmental effects (Flemming \& Trevors, 1989; Hoff et al., 1998) and formalin is carcinogenic (Doane \& Sarenbo, 2014). These impacts show the need for more experimental research on new chemicals or discovering the most effective use of the existing products. It is important to determine how often footbaths should be performed based on the hygiene score (Reneau et al., 2005). In order to increase the effectiveness of footbaths, cleaning animal's feet before entering the bath solution is important. The passage of animals in footbaths must be comfortable and the possibility of slipping should be eliminated. Mismanagement of one or more of these key points may decrease efficacy regardless of which footbath is used. Nevertheless, there is a broad variety in on-farm practices related to footbath protocols (Cook et al., 2012; Relun et al., 2013; Solano et al., 2015).

It was aimed to determine the relationship between footbath use and the number of active lesions related to DD. The protocol based on current scientific literature including footbath chemicals and management practice.

\section{Materials and Methods}

\section{Farm and Cow Selection}

A total of 6 freestall dairy farms in Aydin province in Turkey were contacted by a phone call to be enrolled as part of a longitudinal study. We selected the farms that met the requirements of the study. The requirements of the farms were; to have a freestall housing with no access to pasture, the herd size should be more than 50 lactation cows, cows had to milk in a milking parlor and farms had to have a DD prevalence (regardless of six M-stage) of $\geq 10 \%$. Six farms met all criteria and agreed to participate in the study from July 2016 to July 2017. The Turkish Scientific Council of Turkey (2209/A, Application Number- 1919B011602116) approved all of the methods.

\section{Study Design}

A longitudinal observational study was conducted on

Table 1. Detailed table about footbath application practice from six dairy farms in Aydin, Turkey

\begin{tabular}{|c|c|c|c|c|}
\hline Farm & Bedding type & $\begin{array}{l}\text { Footbath dimensions (length } \\
\times \text { width } \times \text { height })(\mathrm{cm})\end{array}$ & Active Component & $\begin{array}{c}\text { The number of foot- } \\
\text { bath application days } \\
\text { per week * }\end{array}$ \\
\hline 2 & Dry Manure & $100 \times 300 \times 15$ & $\mathrm{CuSO}_{4}$ & $2 d$ \\
\hline 3 & Dry Manure & $90 \times 300 \times 20$ & $\mathrm{CuSO}_{4}$ & $3 d$ \\
\hline 4 & Rubber Mattress & $100 \times 200 \times 10$ & Formalin & $5 d$ \\
\hline 6 & Dry Manure & - & - & - \\
\hline
\end{tabular}

*All farms except farm 6, applied footbath practices after milking. 
Table 2. Distribution and prevalence of digital dermatitis (DD) lesions in farms

\begin{tabular}{|c|c|c|c|c|c|c|}
\hline \multirow{2}{*}{ Farm } & \multirow{2}{*}{$\begin{array}{l}\text { Number of cattle affected by } \\
\text { digital dermatitis/ } \\
\text { total number of cattle (\%) }\end{array}$} & \multicolumn{4}{|c|}{ Affected Legs* } & \multirow{2}{*}{$\begin{array}{c}\text { Total number of legs affected } \\
\text { by digital dermatitis, } \\
\text { n (\%) }\end{array}$} \\
\hline & & $\mathbf{R F}$ & LF & LH & $\mathbf{R H}$ & \\
\hline 1 & 39 / 160 (24.38) & 2 & - & 28 & 23 & 53 (33.97) \\
\hline 2 & 97 / 203 (47.78) & 8 & 11 & 67 & 78 & $164(42.27)$ \\
\hline 3 & 81 / 224 (36.16) & - & 1 & 57 & 55 & $113(34.88)$ \\
\hline 4 & 62 / 543 (11.42) & 43 & - & 39 & - & $82(33.06)$ \\
\hline 5 & 49 / 272 (18.01) & 1 & 1 & 31 & 38 & $71(36.22)$ \\
\hline 6 & $10 / 125(8.00)$ & 1 & 1 & 9 & 6 & $17(3.40)$ \\
\hline Total, n (\%) & 338 / 1527 (22.13) & 55 & 14 & 231 & 200 & $500(8.18)$ \\
\hline
\end{tabular}

* RF: Right front leg, LF: Left front leg, LH: Left hind leg, RH: Right hind leg

the selected farms. All lactating cows were assessed for DD lesions in the milking parlor. The 6 farms were visited on predetermined days to gathering information about prevalence of DD, farm structure, footbath and management practice (Table 1). We inspected the entire lactating herd in the milking parlor. Farmers were encouraged to continue their regular individual treatments for DD.

\section{General Management}

A questionnaire was conducted in each farm. The questions were either open-ended (e.g." What is the active ingredient used as a footbath?) (Table 1) or closed-ended (e.g.," Do you use a footbath on the farm?; response scale: yes or no). Specific information on the frequency of its use (how many times per week) and the renewing frequency of solutions also obtained from the questionnaire. In addition, the dimensions of footbaths measured (length, depth, and width) on each farm (Table 1).

\section{Assessment of Digital Dermatitis Lesions}

According to Döpfer et al. (1997), the DD lesions were scored by using the six $\mathrm{M}$ stages. The skin categorized as M5, if it was normal and without any DD-compatible lesions. Lesions were categorized as $\mathrm{M} 1$, if a small focal clinical lesion ( $<2 \mathrm{~cm}$ in diameter) observed, with redgray surface and small red foci dispersed $(\sim 1 \mathrm{~mm}$ in diameter), M2 if an ulcerative active lesion of around 2 $\mathrm{cm}$ in diameter observed, with extensively mottled a redgray surface. M3 (healing stage) was determined if the lesion has a dry brown and scab-like tissue. This typically seen within a few days of topical treatment. Lesions were categorized as M4 (chronic stage) if a tan irregular hyperkeratotic surface was observed. M4.1 was chronic stage with a small active painful M1 focus. A professional observer completed all DD assessments throughout the presented study. Except M5, other M stages recorded as digital dermatitis.

\section{Milking Parlor Inspection}

Throughout the entire study, we visited each farm to obtain the correlation between footbath usage and its effects on the prevalence of digital dermatitis. During milking, we washed cow's hind and front feet with hose water before the examination to get a clear image of the lesion if present.

\section{Statistical Analyses}

We entered all gathered data into Excel (Microsoft Corp., Redmond, WA) and performed all statistical analyses using IBM SPSS Statistic $22.0^{\circ}$ (IBM, Armonk, NY). A $p$-value of $<0.05$ considered significant for all analyses. The relationship between footbath use and the number of active lesions related to DD examined using the "Chi - Square" test.

\section{Results}

Average herd size was 254.5 lactating cows (range, 125 to 543). Footbaths had a median length of $108 \mathrm{~cm}$ (range, 90 to 150), width of $250 \mathrm{~cm}$ (range, 150 to 300) and a mean depth of $14 \mathrm{~cm}$ (range, 10 to 20). Two farms used a combination of two active chemicals $\left(\mathrm{CuSO}_{4}\right.$ and Formalin). All farms had an individual DD treatment protocol in place. Farm number 3 and 4 renewed their footbath after milking, whereas farm number 1, 2 and 5 did not renew it regularly.

\section{Digital Dermatitis Prevalence}

A total of 6108 observations on 1527 lactating cows (6108 feet) in 6 farms were collected throughout the study period. As a result, Digital Dermatitis observed in 500 feet $(8.2 \%)$ of 338 (22.1\%) dairy cows in total. 5608 feet classified as healthy (no DD lesions) (91.8\%) (Table 2).

\section{Associations Between Digital Dermatitis and Footbath Managements}

The existence of digital dermatitis cases was statistically significant between dry manure (farm no: 1, 2, 3, and 6) (farm no: 1, 2, 3, and 6) with rubber mattress bedding (farm no: 4$)$ practices $(p<0.001)$. There was also a statistically significant difference in the presence of digital dermatitis between straw (farm no: 5) with dry manure bedding (farm no: 1, 2, 3, and 6) practices $(p<0.001)$. There were statistically significant differences between $\mathrm{CuSO}_{4}$ (farm no: 4) and $\mathrm{CuSO}_{4}$ +formalin (farm no: 1 and 5) farms on the relationship between the use 
Table 3. Digital dermatitis (DD) lesion distribution and their association with management factors

\begin{tabular}{|c|c|c|c|c|c|}
\hline & & \multicolumn{2}{|c|}{ Number of DD Lesions ( $n$ ) } & \multirow{2}{*}{ Farm Number } & \multirow{2}{*}{$\mathbf{P}$-value } \\
\hline & & Exist & Non-Exist & & \\
\hline \multirow{3}{*}{ Bedding material } & Dry Manure & 227 & 485 & $(1,2,3,6)^{a}$ & \multirow{3}{*}{$<0.001$} \\
\hline & Straw Bedding & 49 & 223 & $(5)^{b}$ & \\
\hline & Rubber Mattress & 62 & 481 & $(4)^{b}$ & \\
\hline \multirow{4}{*}{ Active chemical } & $\mathrm{CuSO}_{4}$ & 178 & 249 & $(2,3)^{\mathrm{a}}$ & \multirow{4}{*}{$<0.001$} \\
\hline & Formalin & 62 & 481 & $(4)^{a}$ & \\
\hline & CuSO4, Formalin & 88 & 344 & $(1,5)^{b}$ & \\
\hline & Not Used & 10 & 115 & $(6)^{b}$ & \\
\hline \multirow{5}{*}{$\begin{array}{l}\text { Frequency of footbath } \\
\text { application per week? }\end{array}$} & 2 & 155 & 320 & $(2,5)^{\mathrm{a}}$ & \multirow{5}{*}{$<0.001$} \\
\hline & 3 & 81 & 143 & $(3)^{\mathrm{a}}$ & \\
\hline & 5 & 62 & 481 & $(4)^{\mathrm{a}}$ & \\
\hline & 7 & 39 & 121 & $(1)^{\mathrm{b}}$ & \\
\hline & Not Used & 10 & 115 & $(6)^{\mathrm{a}}$ & \\
\hline
\end{tabular}

* Different superscript letters indicate statistical significance.

and types of active chemicals and the existence of digital dermatitis $(p<0.001)$. The existence of digital dermatitis lesions was statistically significant $(p<0.001)$ on farms with footbath use with $\mathrm{CuSO}_{4}+$ Formalin (farm no: 1 and 5) and no footbath used dairy farms (farm no: 6). There was a statistically significant difference in digital dermatitis existence between farms that used formalin as an active chemical on footbath (farm no: 4) and farms that did not use footbath practice (farm no: 6) $(p<0.001)$. According to the frequency of footbath use, digital dermatitis lesion cases were statistically higher $(p<0.001)$ in farms (farm numbers 2 and $3,4,5)$ that did not renew or did not implement any footbath in their farm (farm no: 6).

\section{Discussion}

In this study, the prevalence of DD lesions in herds was associated with footbath management. As an interpretation, footbath practices among producers remain empirical as it relies on mouth-to-mouth advice from other farmers leading non-standardized managements (Relun et al., 2013).

It is widely known that inadequate hygiene is leading to digital dermatitis (Potterton et al., 2012). Dairy management practices such as floor scrapping, bedding material, and cow's diet may directly affect environmental hygiene and lead to contaminated footbaths. The defecation rates inside of the footbath were mentioned in previous studies (Fjeldaas et al., 2014). A previous study claimed that cows can defecate in the alleys between the milking parlor and footbath after adaptation of frequent renewal of footbaths (Ariza et al., 2019). The renewal rate of footbath can affect the defecation rate inside the footbath therefore decrease the contamination of footbath solution especially for the farms with a long interval (Ariza et al., 2019). Also, a large volume of footbaths and less frequency of renewal might lead footbath solutions to a slurry include manure, urine, and dirt (Holzhauer et al., 2006). The close and frequent contact of the feet with slurry might alter the skin permeability, and increase the risk of infection (Palmer et al., 2013). Solano et al. (2017) investigated the influence of literature guidelines concerning footbath dimensions and protocols using a footbath protocol of $5 \% \mathrm{CuSO}_{4}$ for 4 consecutive milking ( 2 days), with a limitation of 200 total passing cows. They assumed that footbath dimensions and changing frequency might have an effect in the prevalence of DD lesions. In our present findings, average value of footbath dimensions was $108 \mathrm{~cm} \times 250$ $\mathrm{cm} \times 14 \mathrm{~cm}$, whereas just two of the farms renewed their footbaths regularly after milking. There were statistically significant differences between footbath used and not used dairy farms $(p<0.001)$. Interestingly, there was no statistically significant difference in between farms with footbaths in terms of frequency of footbath use (Table $3)$.

The presence of feces creates a suitable environment for DD factors (Sullivan et al., 2015). Similarly, in the present study, the prevalence of DD lesions was more common in farms using dry manure as a bedding material. The possible reason for this is that rain and constant urination are unable to avoid. If not managed properly, it should be assumed that the causative source could be the bedding material used, and it should assess that DD lesions may be more prominent. In the present study, there were statistically significant differences on cases of digital dermatitis lesions between dry manure bedding with straw or rubber mattress used dairy farms as a bedding material $(p<0.001)$. This result may be related with the use of dry manure which led an environment for DD lesions on dairy farms.

In the present findings, there were statistically significant differences on DD lesions cases with footbath practices and active chemical used in footbaths (Table $3, p<0.001$ ). 
Despite the widespread use and proven effectiveness of footbaths (Laven \& Logue, 2006), footbathing is an expensive practice primarily due to labor costs (Bruijnis et al., 2013). On the other hand, the advantages of providing clear and accurate footbath procedures may lead to a decreased incidence of DD and, therefore, lower costs associated with hoof trimming, treatments, and a high benefit to welfare. However, in the present study, there was no footbath in Farm No: 6, and Digital Dermatitis lesions were detected in $8.0 \%$ of the population. As a limitation, the concentration of used footbath chemicals, renew rate of the farm number 1, 2 and 5 , the chemical amount used in footbaths, hygiene of the walking alleys or claws were not taken into account in the present study due to limited visit days to the farms and the willingness of not intervene any protocol in farms. This may be related to the present study's finding such as there was no statistically significant relationship between the use of combined use of $\mathrm{CuSO}_{4}+$ formalin and digital dermatitis prevalence (Table 3 ). It may be more beneficial not to use a footbath at all, than if it is not prepared properly.

\section{Conclusion}

The use of footbath is very important in terms of the prevalence of digital dermatitis. Mentioning these results in farms that exist or will be built in similar climatic geographic regions may help to decrease the prevalence of digital dermatitis. Furthermore, instead of inappropriate usage on fields, it might be best not to use footbath at all.

\section{Acknowledgement}

Authors would like to thanks to The Scientific and Technological Research Council of Turkey for funding the research project 2209/ A, Application Number1919B011602116 and Aykut Göktürk Üner for their contributions to statistical analysis.

\section{Conflict of Interest}

The authors declare that they have no conflicts of interest.

\section{References}

Akin, I., \& Akin, T. (2018). Economic impact of digital dermatitis treatment on a dairy farm: an application of the break-even analysis. Ciência Rural, 48(8). 10.1590/01038478cr20170791.

Apley, M. D. (2015). Clinical evidence for individual animal therapy for papillomatous digital dermatitis (hairy heel wart) and infectious bovine pododermatitis (foot rot). Veterinary Clinics of North America: Food Animal Practice, 31(1), 81-95. 10.1016/j. cvfa.2014.11.009.

Ariza, J. M., Bareille, N., Oberle, K., \& Guatteo, R. (2019). Current recommendations for footbath solutions renewal rates in dairy cattle: the need for adaptation? Animal, 13(6), 1319-1325. 10.1017/ S1751731118002847.

Blowey, R. (2005). Factors associated with lameness in dairy cattle. In Practice, 27(3), 154-162. 10.1136/inpract.27.3.154.

Blowey, R. W., \& Sharp, M.W. (1988). Digital dermatitis in dairy cattle. Veterinary Record, 122(21), 505-508.-10.1136/vr.122.21.505.

Blowey, R.W., Carter, S.D., White, A. G., \& Barnes, A. (1994). Borrelia burgdorferi infections in UK cattle: a possible association with digital dermatitis. Veterinary Record, 135(24), 577-578.

Bruijnis, M. R., Beerda, B., Hogeveen, H., \& Stassen, E. N. (2012). Assessing the welfare impact of foot disorders in dairy cattle by a modeling approach. Animal, 6(6), 962-970. 10.1017/ S1751731111002606.

Bruijnis, M. R., Hogeveen, H., \& Stassen, E. N. (2013). Measures to improve dairy cow foot health: consequences for farmer income and dairy cow welfare. Animal, 7(1), 167-175. 10.1017/ S1751731112001383.

Bruijnis, M.R., Hogeveen, H., \& Stassen, E.N. (2010). Assessing economic consequences of foot disorders in dairy cattle using a dynamic stochastic simulation model. Journal of Dairy Science, 93(6), 2419-2432. 10.3168/jds.2009-2721.

Cha, E., Hertl, J.A., Bar, D., \& Grohn, Y.T. (2010). The cost of different types of lameness in dairy cows calculated by dynamic programming. Preventive Veterinary Medicine, 97(1), 1-8. 10.1016/j.prevetmed.2010.07.011.

Cheli, R., \& Mortellaro, C. (1974). La dermatite digitale del bovino. In Proceedings of the 8th International Conference on Diseases of Cattle, Piacenza, Milan, pp.208-213.

Cook, N.B., Rieman, J., Gomez, A., \& Burgi, K. (2012). Observations on the design and use of footbaths for the control of infectious hoof disease in dairy cattle. The Veterinary Journal, 193(3), 669-673. 10.1016/j.tvjl.2012.06.051.

Cramer, G., Lissemore, K.D., Guard, C.L., Leslie, K.E., \& Kelton, D.F. (2008). Herd- and cow-level prevalence of foot lesions in Ontario dairy cattle. Journal of Dairy Science, 91(10), 3888-3895. 10.3168/ jds.2008-1135.

Doane, M., \& Sarenbo, S. (2014). Exposure of farm laborers and dairy cattle to formaldehyde from footbath use at a dairy farm in New York State. Science of the Total Environment, 487, 65-71. 10.1016/j. scitotenv.2014.04.007.

Döpfer, D., Anklam, K., Mikheil, D., \& Ladell, P. (2012). Growth curves and morphology of three Treponema subtypes isolated from digital dermatitis in cattle. The Veterinary Journal, 193(3), 685-693. 10.1016/j.tvjl.2012.06.054.

Döpfer, D., Holzhauer, M., \& Boven, M. (2012). The dynamics of digital dermatitis in populations of dairy cattle: model-based estimates of transition rates and implications for control. The Veterinary Journal, 193(3), 648-653. 10.1016/j.tvjl.2012.06.047.

Döpfer, D., Koopmans, A., Meijer, F. A., Szakáll, I., Schukken, Y. H., Klee, W., Bosma, R. B., Cornelisse, J. L., van Asten, A. J., \& ter Huurne, A. A. (1997). Histological and bacteriological evaluation of digital dermatitis in cattle, with special reference to spirochaetes and Campylobacter faecalis. The Veterinary record, 140(24), 620-623. 10.1136/vr.140.24.620

Ettema, J., Ostergaard, S., \& Kristensen, A.R. (2010). Modelling the economic impact of three lameness causing diseases using herd and cow level evidence. Preventive Veterinary Medicine, 95(1-2), 64-73. 10.1016/j.prevetmed.2010.03.001.

Evans, N.J., Timofte, D., Isherwood, D.R., Brown, J.M., Williams, J.M., Sherlock, K., \& Carter, S.D. (2012). Host and environmental reservoirs of infection for bovine digital dermatitis treponemes. Veterinary Microbiology, 156(1-2), 102-109. 10.1016/j.vetmic.2011.09.029.

Fjeldaas, T., Knappe-Poindecker, M., Boe, K.E., \& Larssen, R.B. (2014). Water footbath, automatic flushing, and disinfection to improve the health of bovine feet. Journal of Dairy Science, 97(5), 28352846. 10.3168/jds.2013-7531.

Flemming, C.A., \& Trevors, J.T. (1989). Copper toxicity and chemistry in the environment: a review. Water, Air, and Soil Pollution, 44(1), 143-158. 10.1007/BF00228784.

Gillespie, A.V., Carter, S.D., Blowey, R.W., Staton, G.J., \& Evans, N.J. (2020). Removal of bovine digital dermatitis-associated treponemes from hoof knives after foot-trimming: a disinfection field study. BMC Veterinary Research, 16(1), 330. 10.1186/s12917-020-02552-8.

Gomez, A., Cook, N.B., Rieman, J., Dunbar, K. A., Cooley, K.E., Socha, M.T., \& Dopfer, D. (2015). The effect of digital dermatitis on hoof conformation. Journal of Dairy Science, 98(2), 927-936. 10.3168/ jds.2014-8483.

Hoff, B., Boermans, H.J., \& Baird, J.D. (1998). Retrospective study of toxic metal analyses requested at a veterinary diagnostic toxicology 
laboratory in Ontario (1990-1995). Canadian Veterinary Journal, 39(1), 39-43.

Holzhauer, M., Döpfer, D., de Boer, J., \& van Schaik, G. (2008). Effects of different intervention strategies on the incidence of papillomatous digital dermatitis in dairy cows. Veterinary Record, 162(2), 41-46. 10.1136/vr.162.2.41.

Holzhauer, M., Hardenberg, C., Bartels, C.J., \& Frankena, K. (2006). Herd- and cow-level prevalence of digital dermatitis in the Netherlands and associated risk factors. Journal of Dairy Science, 89(2), 580-588. 10.3168/jds.S0022-0302(06)72121-X.

Krull, A.C., Cooper, V.L., Coatney, J.W., Shearer, J.K., Gorden, P.J., \& Plummer, P.J. (2016). A Highly Effective Protocol for the Rapid and Consistent Induction of Digital Dermatitis in Holstein Calves. PLOS ONE, 11(4), e0154481. 10.1371/journal.pone.0154481.

Laven, R.A., \& Logue, D.N. (2006). Treatment strategies for digital dermatitis for the UK. The Veterinary Journal, 171(1), 79-88. 10.1016/j.tvjl.2004.08.009.

Nuss, K. (2006). Footbaths: the solution to digital dermatitis? The Veterinary Journal, 171(1), 11-13. 10.1016/j.tvjl.2005.02.010.

Palmer, M.A., Donnelly, R.F., Garland, M.J., Majithiya, R., \& O'Connell, N.E. (2013). The effect of slurry on skin permeability to methylene blue dye in dairy cows with and without a history of digital dermatitis. Animal, 7(10), 1731-1737. 10.1017/s1751731113001274.

Potterton, S.L., Bell, N.J., Whay, H.R., Berry, E.A., Atkinson, O.C., Dean, R.S., \& Huxley, J.N. (2012). A descriptive review of the peer and non-peer reviewed literature on the treatment and prevention of foot lameness in cattle published between 2000 and 2011. The Veterinary Journal, 193(3), 612-616. 10.1016/j.tvjl.2012.06.040.

Read, D.H., \& Walker, R.L. (1998). Papillomatous digital dermatitis (footwarts) in California dairy cattle: clinical and gross pathologic findings. Journal of Veterinary Diagnostic Investigation, 10(1), 6776. $10.1177 / 104063879801000112$.

Relun, A., Guatteo, R., Auzanneau, M.M., \& Bareille, N. (2013). Farmers' practices, motivators and barriers for adoption of treatments of digital dermatitis in dairy farms. Animal, 7(9), 1542-1550. 10.1017/ s1751731113000803.

Relun, A., Lehebel, A., Bareille, N., \& Guatteo, R. (2012). Effectiveness of different regimens of a collective topical treatment using a solution of copper and zinc chelates in the cure of digital dermatitis in dairy farms under field conditions. Journal of Dairy Science, 95(7), 37223735. 10.3168/jds.2011-4983.

Reneau, J.K., Seykora, A.J., Heins, B.J., Endres, M.I., Farnsworth, R.J., \& Bey, R.F. (2005). Association between hygiene scores and somatic cell scores in dairy cattle. Journal of the American Veterinary Medical Association, 227(8), 1297-1301. 10.2460/javma.2005.227.1297.

Rodríguez-Lainz, A., Hird, D.W., Walker, R.L., \& Read, D.H. (1996). Papillomatous digital dermatitis in 458 dairies. Journal of the American Veterinary Medical Association, 209(8), 1464-1467.

Scholey, R., Ollier, W., Blowey, R., Murray, R., \& Carter, S. (2010). Determining host genetic susceptibility or resistance to bovine digital dermatitis in cattle. Advances in Animal Biosciences, 1(1), 2-2.

Solano, L., Barkema, H.W., Mason, S., Pajor, E.A., LeBlanc, S.J., \& Orsel, K. (2016). Prevalence and distribution of foot lesions in dairy cattle in Alberta, Canada. Journal Dairy Science, 99(8), 6828-6841. 10.3168/jds.2016-10941.

Solano, L., Barkema, H.W., Pajor, E.A., Mason, S., LeBlanc, S.J., Zaffino Heyerhoff, J.C., \& Orsel, K. (2015). Prevalence of lameness and associated risk factors in Canadian Holstein-Friesian cows housed in freestall barns. Journal of Dairy Science, 98(10), 6978-6991. 10.3168/jds.2015-9652

Solano, L., Barkema, H.W., Pickel, C., \& Orsel, K. (2017). Effectiveness of a standardized footbath protocol for prevention of digital dermatitis. Journal of Dairy Science, 100(2), 1295-1307. 10.3168/ jds.2016-11464.

Speijers, M.H., Baird, L.G., Finney, G.A., McBride, J., Kilpatrick, D.J., Logue, D.N., \& O'Connell, N.E. (2010). Effectiveness of different footbath solutions in the treatment of digital dermatitis in dairy cows. Journal of Dairy Science, 93(12), 5782-5791. 10.3168/ jds.2010-3468.

Sullivan, L.E., Evans, N.J., Blowey, R.W., Grove-White, D.H., Clegg, S.R.,
Duncan, J. S., \& Carter, S.D. (2015). A molecular epidemiology of treponemes in beef cattle digital dermatitis lesions and comparative analyses with sheep contagious ovine digital dermatitis and dairy cattle digital dermatitis lesions. Veterinary Microbiology, 178(1-2), 77-87. 10.1016/j.vetmic.2015.04.011. 